\title{
Social skills and locus of control of teenage mothers and pregnant teens placed at the Polish Correctional Institutions. Report of studies
}

\author{
Beata Maria Nowak ${ }^{1, *}$, Jacek Krawczyk ${ }^{2, * *}$ \\ ${ }^{1}$ Pedagogium - Higher School of Social Sciences in Warsaw, \\ 115 Marszałkowska St., 00-102 Warszawa, Poland \\ ${ }^{2}$ National School of Public Administration, 56 Wawelska St., 00-922 Warszawa, Poland \\ ${ }^{*, * \star E-m a i l ~ a d d r e s s: ~ n o w a k . b e a t a . m a r i a @ g m a i l . c o m ~, k a-j a c e k @ w p . p l ~}$
}

\begin{abstract}
The purpose of the article is the presentation of the results of research aiming at the assessment of the level of social competences and locus of control of teenage mothers and pregnant teens placed at the correctional institutions as the variables significantly determining the way of functioning in the society (more broadly - functioning in the environment).
\end{abstract}

Keywords: teenage mothers; correctional institutions; social competences; locus of control

\section{INTRODUCTION}

Social skills are essential in order to manage oneself properly in the context of the effectiveness of actions undertaken by a person in social situations. The most common indicators of this effectiveness are: the achievement of an individual's own goals and the compliance of their behaviour with social expectations. In other words, the essence of social skills is the ability to reconcile one's own interests with the interests of society, and following this, to deal with the differences between individual and socially important goals (Oppenheimer 1989).

The effectiveness of social training that an individual is subject to throughout life is determined by his/her intellectual capabilities. While intensity and type - temperament and personality traits (e.g. extra-introversion, reactivity - activity, anxiety, impulsiveness thoughtfulness, cognitive curiosity - caution) (Matczak 2001; Smółka 2008). Environmental conditions, training and therapeutic influences, both intentional (including educational), and unintentional also play a large role, as do - what seems to be extremely important in the described situation - normative influences of one's own socio-environmental enclaves (local communities with their internal standards, codes and rituals) ${ }^{1}$.

\footnotetext{
${ }^{1}$ At this point, it seems essential to emphasize that the point of reference for distinguishing attitudes and behaviours in the scope of social maladjustment or poor social performance, is the social and cultural norm specified as the accepted and commonly applicable. Indeed, the same attitudes and behaviours presented in one's own local environment do not have to be perceived this way, on the contrary - they can be not only acceptable,
} 
A high level of social skills is a primary predictor of satisfactorily developing and sustaining a network of social contacts and presentation of one's own credibility (Spitzberg, Cupach 2002). It enables to produce an atmosphere of trust and control over unusual situations and complex interpersonal relationships. Social skills are also conducive to mastering the ability of observing and controlling one's own expression and self-presentation, through which a person can effectively modify his/her own behaviour in response to the requirements of the social environment. A high level of social skills is associated with an individual's better adaptation to life changes, a higher plasticity of behaviours and attitudes in a variety of social situations, as well as lower indicators of anxiety, depression or the feeling of loneliness (Strelau 2002). Well-developed social skills also condition the emergence of the tendency to consciously create one's own individual and social identity, as well as tendencies and abilities of manifesting behaviours that are adequate to social situations and ones leading to the realization of set goals (Czarnota-Bojarska 1997; Świątnicki 1994).

However, locus of control (LOC) is just as important for the effectiveness of actions taken by a person in social situations. In accordance with the definition provided by Rotter - it is an individual feature of the human being, which can be treated as a dimension of personality, forming a continuum from external locus of control (external LOC) to internal locus of control (internal LOC). It should be noted that locus of control can change as a result of learning, based on the individual's subjective perception of their own impact on the results of their behaviour. Internal LOC is shaped as a result of a person frequently experiencing situations of controlling the results of his/her own actions. External LOC on the other hand crystallizes as a result of the individual's conviction that the results of his/her actions depend on random factors, other people or institutions. Aside from the process of individual development based on learning within the psychological meaning, (collecting experience), it can also be determined by social factors and intentional effects - educational methods or training techniques, applied during school education (Domachowski, Kowalik, Miluska 1994).

The study presented in this article is part of a larger research project, associated with the issue of underage mothers and pregnant charges of correctional facilities ${ }^{2}$.

\section{REPORT OF STUDIES}

\section{1. Methodological objectives}

The purpose of the study, which was carried out in June 2013, was to collect (based on questionnaire studies) information on the personality profiles of underage mothers and pregnant women - charges of correctional institutions. It was assumed that the results obtained will constitute a database for the development of a model of systemic measures for the needs of conducting correctional measures in relation to the analyzed group.

With regard to the specifics of the studied population, the fact was taken into consideration that deficits in communication and persuasive skills are a restraint for attaining goals (life, educational, professional aspirations) and may seriously hinder the effective performance of obligations imposed on the individual in the form of socio-cultural standards in the course of family and social life (Adler, Rosenfeld, Proctor 2006). The deficiency or low

but also expected. Not complying to these standards may result in various types of repression, including marginalisation, or even exclusion from this local community.

${ }^{2}$ Raport z realizacji projektu "Chcę być z Tobą MAMO!" (http://www.podrugie.pl/wpcontent/uploads/2013/11/RAPORT.pdf.) 
level of social skills, which is the result of flawed (other than commonly acceptable) socialization of individuals, contributes to the existence of many manifestations of behaviours assessed as social maladjustment (e.g. criminal and aggressive behaviour, as well as others that are incompatible with social expectations, but not as clearly negative, for instance homelessness by choice).

By assuming that people have different sets of skills, just like suitability profiles, it can be assumed that social maladjustment of an individual or poor efficiency of its social effect can be the result of: the lack of certain predispositions; inadequately formed skills; low level of competence; underestimating one's own abilities (low self-esteem); insufficient awareness of one's own potential (within the meaning of readiness to use one's own resources in overcoming difficult situations) or ambiguity as to the specified social role (Smółka 2008). It can also finally be a matter of an individual's conscious choice. And although such circumstances are not the subject of this paper, it still cannot be overlooked.

As A. Jaworowska's and A. Matczak's (2003) research shows, there is a link between the lack of social skills, and difficulties of an individual adapting. A. Matczak (2007) also indicates the correlations between the level of social skills of children and the upbringing styles of parents. These correlations and the thesis of the instability of social skills with time gave grounds to assume that social training may significantly influence raising the level of social skills.

The second feature studied, i.e. locus of control, can have both the character of a generalized expectation, as well as specific situational expectations associated with perceiving the effects of one's actions undertaken within the framework of playing a given social role (the greater share of generalized expectations takes place if a given situation is perceived as relatively new) (Krasowicz, Kurzyp-Wojnarowska 1990).

Studies of characteristics and tendencies of people with an internal or external locus of control, thus far indicate the existence of significant differences between the two groups. People with internal LOC are characterized by a higher self-esteem and self-acceptance. They are more likely to claim the responsibility for successes, are less likely to change opinions, show greater sensitivity to information, see more opportunities for action, and undertake action in emergency situations easier. While the lack of locus of control over action (external LOC) causes the emergence of a sense of alienation and estrangement and, as a consequence, preferring forms of activities - specific to low self-esteem (Ibid.).

In light of the above, the presented studies were aimed to determine the level of social skills and locus of control (internal - external) of the studied group of charges, as those variables, which significantly determine social functioning (in the broader sense how one functions in the environment).

It has been assumed here that the results of the study shall constitute the basis for forming models of stabilizing-developmental and resocialization-destigmatizing effects towards the studied population of underage charges of correctional institutions (Nowak 2012).

The presented study has been conducted on the basis of two tools: the Social Skills Questionnaire (Kwestionariusz Kompetencji Społecznych - KKS) A. Matczak, and Locus of Control Study Questionnaire (Kwestionariusz do Badania Poczucia Kontroli - KBPK) G. Krasowicz and A. Kurzyp-Wojnarska. Both tools refer to temperamental and personality aspects, i.e. describing those behaviours that are based on relatively stable individual conditions, defining the individual's natural strategies of acting.

KKS Questionnaire is used to assess social skills understood as acquired skills which condition the effectiveness of a person functioning in different social situations. It measures the social skills in three types of situations: 
- dealing with intimate situations (scale I), meaning close interpersonal contacts in connection with deep disclosure of the interaction's partners, which in practical terms means e.g. confiding in someone and listening to confessions;

- dealing with situations of social exposure (ES scale), meaning being the object of attention and potential evaluation by others;

- dealing with situations that require assertiveness (scale A), understood as pursuing one's own goals or needs by influencing others or resisting this influence. ${ }^{3}$

It consists of 90 positions, constituting noncircumstantial determinants of various actions. The respondent evaluates on the four-level scale the effectiveness with which it is performed. Integrity and accuracy: high coefficients of internal compliance. The accuracy of the questionnaire was confirmed primarily by factor analysis and inter-group comparisons

The KBPK questionnaire is used to measure the personality variable called the sense of control of the consequences of behaviour, described in J.B. Rotter's social learning theory (Krasowicz, Kurzyp-Wojnarowska 1990). It consists of 46 questions, including 36 diagnostic ones. The questions concerning positive events make up the Success scale (S), while the questions concerning negative events make up the Failures scale (F). Low results attest to the feeling of external control, while high results to the feeling of internal control. Reliability and accuracy: KBPK is characterized by satisfactory internal compliance, and the study results confirm the diagnostic and theoretical accuracy of the method.

The analysis of the presented studies was directed to carry out cross-correlations between particular variables, and specify them using any dependencies. As expected by the Authors of the study, the statement of the existence of dependencies or trends should help in the precise extraction of areas that are most sensitive and crucial for forming effective resocialization effects.

As mentioned above, the study was carried out on the basis of two questionnaires describing the attitudes of the respondents in terms of their interaction with the environment. The control variables were socio-demographic variables:

- age of the respondent;

- condition of respondent (pregnancy; maternity);

- age of the charge's child (in the case of mothers);

- family type, which the respondent comes from (complete; incomplete);

- family structure, which the respondent comes from (nuclear family; extended family);

- place of residence (farm and small town; medium-sized and large city);

- education (primary; lower secondary; vocational);

- education of the charge's parents.

\footnotetext{
${ }^{3}$ In accordance with the objectives of KKS, social skills are understood as "complex skills conditioning the effectiveness of dealing with specific types of social situations, acquired by an individual in the course of social training". The effectiveness of training depends on the one hand on the intellectual capabilities of an individual, however, on the other hand on the characteristics of temperament and personality, which affect the frequency and type of social contact preferred, at the same time indicating the amount and type of his/her social experiences. However, it should be noted that this training also depends on the environmental impacts addressed to the individual, both unintended, as well as deliberate (intentional), which is particularly important in the context of the studies conducted. In summary, the individual scales determine the effectiveness of an individual's behaviour in the following situations: intimate, social exposure and ones that require assertiveness. It should be very clearly pointed out that the effectiveness of coping in these situations arises from the subjective assessment of the individual, because effective behaviours are those that are considered to be effective in the process of satisfying needs (also including the reduction of discomfort - i.e. behaviour in stressful situations), and these are an individual matter (Matczak 2011, p. 7).
} 


\section{2. Area of research and characteristics of respondents}

In light of preliminary data (obtained from correctional institutions) it can be assumed that the estimated annual number of events (pregnancy or childbirth) among the charges of these institutions amounts to approx. 60. At the commencement of research there were 48 underage girls - mothers and pregnant girls - in correctional institutions. However, due to high fluctuations of charges during the holiday period (holidays and passes), 30 girls took part in the study - students of primary and junior high schools staying in youth educational centres ${ }^{4}$ (26 people) and in correctional institutions (4 people), representing $62.5 \%$ of the total population being surveyed.

The study was conducted in 20 resocialization institutions fulfilling the criteria of the study: in 4 correctional establishments and 16 YECs (15 YEC for girls and one co-educational facility). In six facilities the presence of one person of the indicated profile was found, while in others from 2 to 8 . In the Polish resocialization system underage persons are those who are: under 18 years old and show signs of social demoralization; over 13 years old, but still under 17 years old and have committed an offence; persons, who have been sentenced to correctional means and these persons are under 21 years old ${ }^{5}$. At the time of the study, 20 underage girls were already mothers (in one case - no data), and nine were pregnant - Fig. no. 1. Among the surveyed underage mothers the majority were over 18 years old (9) and one was 20 years old. According to the information contained in the questionnaires, one of the 15year-olds gave birth to a child in November 2010, which means that she became a mother at the age of 12-13, one in mid-2012 and one in mid-2013.

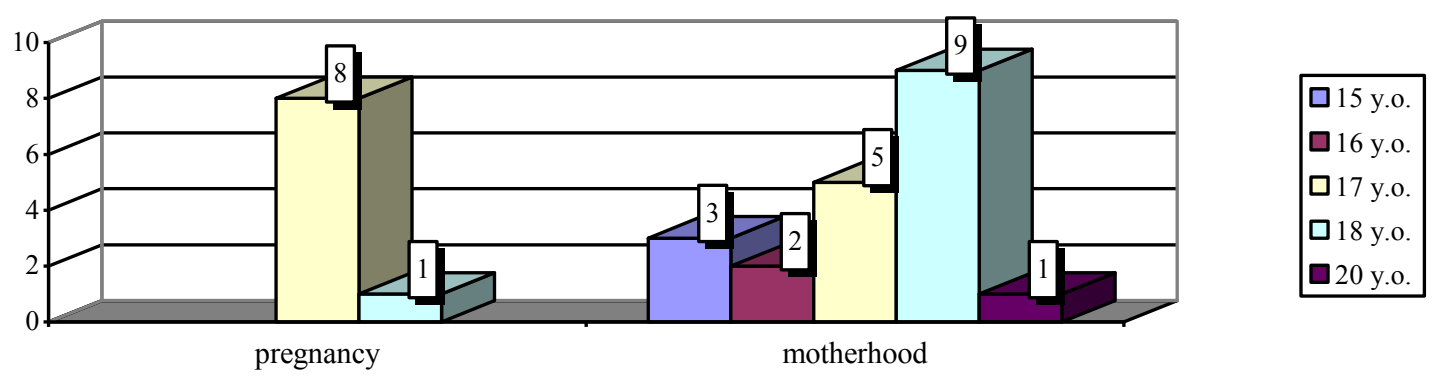

Fig. 1. The age of the girls surveyed and their condition: pregnancy, motherhood.

The majority of pregnant girls were 17 years old (8). Dates of birth were determined for the last quarter of 2013 or for January 2014. One of the respondents, who was pregnant, had already given birth to a child.

There is no doubt that in relation to the cases of the youngest mothers, we are dealing with the phenomenon of early sexual initiation. It should be noted here that the contemporary age of sexual initiation has shifted significantly; hence it is difficult to adopt a point of reference other than the cultural and social standard, or even the legal standard (in Poland, the

\footnotetext{
${ }^{4}$ Youth educational centres (YEC) are resocialization-educational establishments intended exclusively for youth, who have been sentenced by Family and Juvenile Courts (under the Act on proceedings regarding juvenile cases of 26 October 1982 as amended) to an educational centre in the form of placement in a YEC. The basic tasks of a YEC include eliminating the causes and manifestations of social maladjustment and preparing charges for life in accordance with the social and legal standards.

${ }^{5}$ In accordance with the Act of 26 October 1982 contained in the Journal of Laws of 2001 no. 11 item 109 on proceedings in minor cases as amended. Amendments to the consolidated text of the mentioned act were announced in the Journal of Laws of 2011 no. 112, item 654, no. 149, item 887 and no. 191, item 1134, of 2012 item 579 and of 2013 item 628 and 1165.
} 
law states that an adult is a person who has turned 18 years of age). However, while the acceptable age of sexual initiation may be considered to be lowered within certain limits, then the age of motherhood at approx. 13-15 years of age is indisputably socially perceived as too early and the result of negative and antisocial behaviours and patterns ${ }^{6}$.

The charges surveyed mainly come from large and medium-sized cities - Fig. no. 2. In the case of the youngest charges surveyed (three fifteen-year-olds), in two cases, their parents live in a big city, while in one case in a medium-sized city.

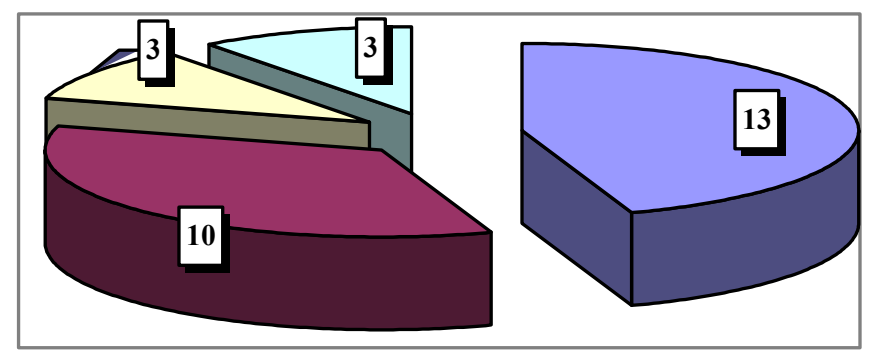

\begin{tabular}{|l|}
\hline large city \\
$\square$ medium-sized city \\
$\square$ small city \\
$\square$ countryside \\
\hline
\end{tabular}

Fig. 2. Place of residence of the parents of surveyed charges.

Nine of the girls surveyed come from complete families, seventeen from broken families - no father, two from broken families - no mother (one of the girls already has a child, the other is pregnant). In two cases, there is a lack of data. Twenty-one of the respondents were raised in elementary families (nuclear), and seven in extended families. In two cases there is a lack of data.

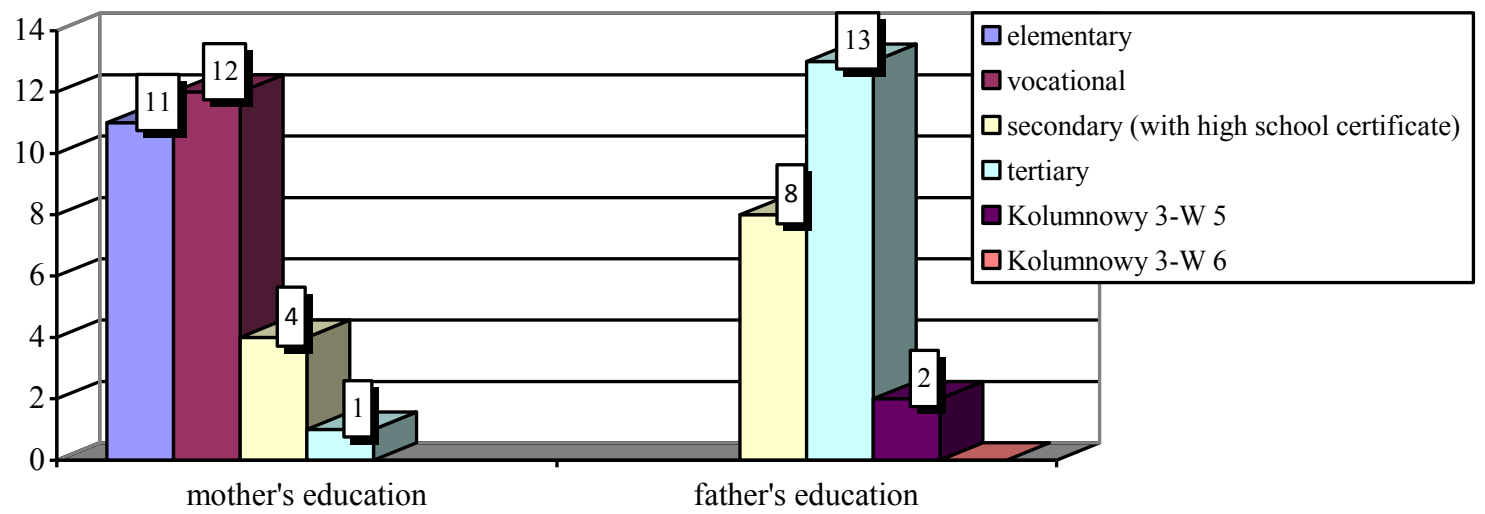

Fig. 3. Level of education of the respondents' parents.

The mothers of the girls surveyed mostly have primary or vocational education, while the fathers usually hold a vocational education - Fig. no. 3. In seven cases data is not provided.

Two of the surveyed girls come from families where both the mother and father hold a secondary education, while the parents of two others - vocational. In one case, the mother has a tertiary education, the father - vocational. In both cases, if the charge surveyed came from a broken family with a father, the father's education was at the vocational level, and the

\footnotetext{
${ }^{6}$ In accordance with the information provided in the questionnaires, one of the fifteen-year-olds gave birth in November 2010, which would mean that she became a mother at the age of approx. 12-13 years old, one around mid-2012 and one around mid-2013.
} 
mother's education was at the primary and vocational level. Four girls, whose mothers have secondary education, already have children (they are mothers) - three of them when giving birth were 17 years old, and one was 15 years old. In the case of a 15-year-old charge, who gave birth to a child at the age of approx. 12-13 (in November 2010), her mother has a tertiary education.

The girls surveyed mostly hold a primary or junior high education (two of the three fifteen-year-olds, one sixteen-year-old, five seventeen-year-olds and one eighteen-year-old) Fig. no. 4.
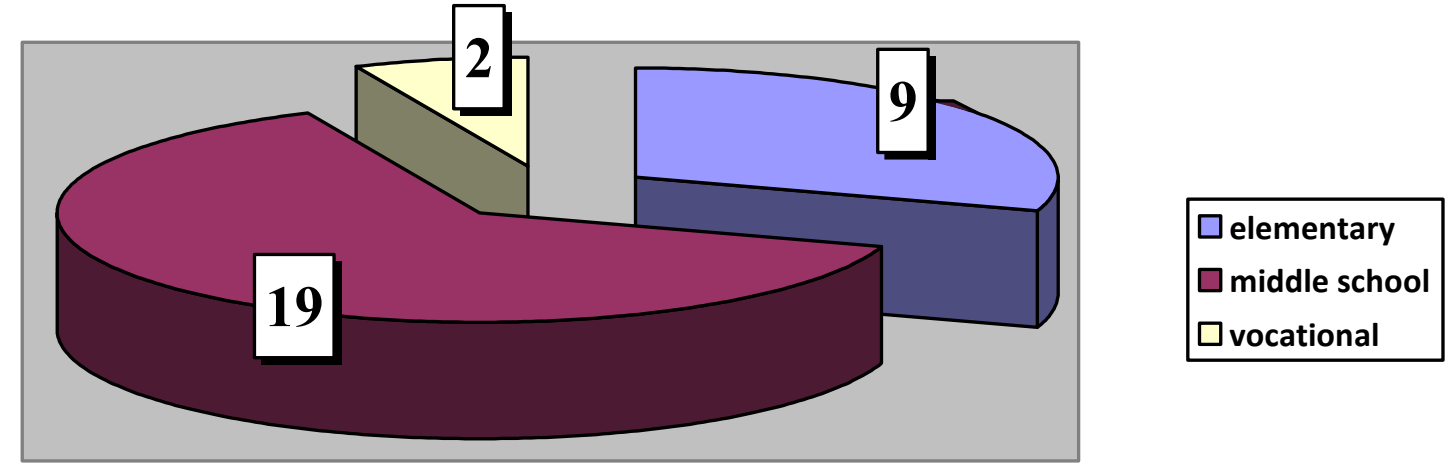

Fig. 4. Education level of respondents.

The desire to continue school education at the vocational level was expressed by 10 girls - all with junior high education. One of the girls who has vocational education expressed interest in continuing her education in technical college. While two girls with junior high education and one with vocational education have declared to complete secondary education (in one case, both parents have secondary education, in the other two, none of the parents have education at a higher level than vocational).

\subsection{Study results}

In reference to the analysis of socio-demographic variables, it is mainly noted that there is a lack of significant links between them and the results of measurements made using KKS and KBPK questionnaires. Of course, it must be agreed that the number of respondents was relatively small, however, the subject of research concerned a specific group of minors mothers and pregnant girls of correctional institutions, and what is important, more than half of this population was surveyed. Therefore, the thesis can be set that the obtained results are relevant in relation to the whole population.

Despite the lack of significant associations between the analysed control variables, the low level of education of the respondents' parents can be clearly noted, as is the low level of education of the surveyed girls themselves, whose biological age definitely exceeds the right age for the specific stage of education in Poland (6-year primary school: 7-13 years old; 3year junior high school: 14-16 years old; from 16 years of age senior high school with different education durations, depending on the type of school). However, this type of pattern is in fact so widely shown (and perhaps even abused) in studies related to attempts at determining the causes of the phenomenon of social maladjustment, that basing the 
conclusion solely on the existence of such a dependence is risky (and is more a manifestation of the investigator's helplessness, than proof of the existence of the actual cause).

As mentioned before, in terms of statistical analysis of the control variables no relevant dependencies (differences) were found between them and the results of the questionnaire study. This means that there are no significant associations between socio-demographic variables and the level of social skills surveyed using the KKS questionnaire and locus of control surveyed using the KBPK questionnaire.

However, a statistically significant (at the level of $\mathrm{R}=0.382 ; \mathrm{p}<0.05$ ) correlation was found between the subscale of the KBPK S (success) and the KKS ES scale (social exposure). This means that the higher the result in the scale determining internal LOC in respect to events evaluated as a success (belief in one's own responsibility for awards and successes), the higher the result in the scale determining social skills, which determines the effectiveness of behaviour in a situation of social exposure.

It should be emphasized that the high result in the scale KBPK S, corresponding to the conviction of internal control of positive consequences of events, also enables more effective manipulation of the environment. People with high scores in this scale attract new situations, enabling to reveal possessed abilities, and the conviction of the effectiveness of one's own actions stimulates them also to undertake a variety of activities that satisfy cognitive needs (including - curiosity and the need for exploration).

At this point, it should be pointed out that the tools used in the study (both KBPK and KKS) are self-descriptive tools and as such, determine the level of the beliefs of the respondents. In other words, this does not talk about adequate (that is, subjective) assessment of values, but about the conviction of one's own value and the level of self-esteem resulting from it. At the same time, however, these subjective assessments reflect the sense of achievement and self-acceptance, and directly regulate undertaken interactions with the environment and - obviously - interactions in various social situations.

The comparison of the average results of scales of both questionnaires also did not reveal the existence of dependencies between the study and control variables. The entire group turned out to be quite uniform, both in terms of the results obtained in the KKS scales and KBPK.

For the most part, the results in the KBPK scales specified internal or neutral LOC. However, it should be noted that these results were mostly on the border between the upper limit of neutral LOC and the lower limit of internal LOC. While the results of the KKS scales were at the level of sten 5-7, which means average results. Only for the subscale of KKS I (within the variable - the respondent's age), for the age category 15-16 years old, the result was at 4 sten, which is also located in average results.

As a result, it should firstly be admitted that there are no grounds for finding that there is a link between the state of the girls surveyed (differentiation in the categories: pregnancy versus motherhood) and locus of control measured by the KBPK questionnaire, or the level of social skills measured by the KKS questionnaire. The study results indicate that there are no significant differences between these groups in terms of mean values, both in the general picture, and between the scales (Tables no. 1 and 2).

Table 1. Averages of scales of questionnaires for the group - Mothers.

\begin{tabular}{|l|c|c|c|c|c|c|}
\hline KBPK_S & KBPK_P & KBPK_SP & KKS_I & KKS_ES & KKS_A & KKS_total \\
\hline 15.41379 & 14.44828 & 29.86207 & 43.55172 & 56.55172 & 49.27586 & 182.6207 \\
\hline
\end{tabular}


Table 2. Averages of scales of questionnaires for the group - Pregnant girls.

\begin{tabular}{|l|c|c|c|c|c|c|}
\hline KBPK_S & KBPK_P & KBPK_SP & KKS_I & KKS_ES & KKS_A & KKS_total \\
\hline 15.46336 & 14.53059 & 29.99555 & 43.50167 & 55.95328 & 49.17019 & 181.7942 \\
\hline
\end{tabular}

Bearing in mind the lack of statistically significant differences between the results of the questionnaires' scales, the thesis can be risked as a result of the analysis of the results obtained, that the fact itself of getting pregnant (currently or earlier - in the case of mothers) can have a certain link with particular skills possessed and locus of control, as the results of the study indicate some independence of the respondents and their relatively large independence in social situations. Therefore, perhaps we are dealing with a situation in which undertaking activity that leads to pregnancy is the result of specific personality and temperamental features, and not situations in which pregnancy is the effect of only shaping these dispositions. In other words, this is the effect of undertaking activity due to the skills possessed, and not in relation to their deficit. Confirmation of a similar hypothesis, however, would require additional research, also providing the selection of a control group.

The standards for the KKS questionnaire set out for girls from secondary schools aged 15-19 years old, i.e. the group closest to the surveyed group (Table no. 3) (Matczak 2011, p. 72), for means of all scales indicates the following: KKS (I) - 5 sten; KKS (ES) -6 sten; KKS - 6 sten; KKS (combined) - 6 sten.

The standards for the KKS questionnaire set out for girls from secondary schools aged 15-19 years old, i.e. the group closest to the surveyed group (Table no. 3) (Matczak 2011, p. 72), for means of all scales indicates the following: KKS (I) - 5 sten; KKS (ES) - 6 sten; KKS - 6 sten; KKS (combined) - 6 sten.

In accordance with the categorization for sten results specified in the KKS textbook, the results in the range of 4-7 sten are average results.

Whereas the standards for the KBPK questionnaire closest to the group surveyed are for youth aged 13-17 years old. The results expressed in sten, the textbook defines high results in the range of 7-10 sten. Means obtained in the study indicate the following: KBPK (S) - 8 sten; KBPK (P) - 6/7 sten; KBPK (SP) - 7 sten, therefore, they are high results, i.e. generally internal LOC (KBPK -P - 6/7 sten: unestablished/internal LOC).

Although the qualitative interpretation contained in the textbook indicates (Krasowicz, Kurzyp-Wojnarowska 1990, p. 35) that a high score in the KBPK (P) scale is connected with the sense of the lack of abilities, insufficient work or too little commitment, it seems that it can be assumed that in the surveyed group we are dealing with a conviction of one's own achievement and sense of responsibility for events, and not with searching for their causes in a series of circumstances. 
Table 3. Descriptive statistics.

\begin{tabular}{|c|c|c|c|c|c|c|c|c|}
\hline \multirow{2}{*}{ Tool } & \multirow{2}{*}{$\mathbf{N}$} & \multirow{2}{*}{ Min. } & \multirow{2}{*}{ Max. } & \multirow{2}{*}{ Mean } & \multirow{2}{*}{$\begin{array}{l}\text { Standard } \\
\text { deviation }\end{array}$} & \multirow{2}{*}{$\begin{array}{l}\text { Standard } \\
\text { error of } \\
\text { mean }\end{array}$} & \multicolumn{2}{|c|}{$\begin{array}{c}\text { Confidence intervals } \\
\text { for the } 95 \% \text { level } \\
\end{array}$} \\
\hline & & & & & & & bottom & top \\
\hline KBPK_S & 30 & 9.00 & 53.00 & 15.4667 & 8.23673 & 1.50381 & 12.51919 & 18.41414 \\
\hline KBPK_P & 30 & 5.00 & 45.00 & 14.5333 & 6.84676 & 1.25004 & 12.08325 & 16.98341 \\
\hline KBPK_SP & 30 & 14.00 & 98.00 & 30.0000 & 14.41742 & 2.63225 & 24.84079 & 35.15920 \\
\hline KKS_I & 30 & 29.00 & 60.00 & 43.5000 & 8.12722 & 1.48382 & 40.59171 & 46.40828 \\
\hline KKS_ES & 30 & 36.00 & 71.00 & 55.9333 & 10.95739 & 2.00054 & 52.01228 & 59.85438 \\
\hline KKS_A & 30 & 33.00 & 68.00 & 49.1667 & 9.34431 & 1.70603 & 45.82284 & 52.51048 \\
\hline KKS total & 30 & 132.00 & 234.00 & 181.7667 & 27.48251 & 5.01760 & 171.9321 & 191.6011 \\
\hline SD & 30 & 42.01 & 73.67 & 57.6119 & 8.55251 & - & - & - \\
\hline
\end{tabular}

It should be noted that generally persons with high scores in the KBPK (we are dealing with such scores in this study) have a sense of internal control of the consequences of events. Due to the above, they will be convinced that what befalls them or shall befall them in the future is the result of their own actions, abilities and effort invested (Ibid., p. 34).

In the context of the analysis of the study's results, the possibility of referring to correlations of KKS and KBPK with selected characteristics of temperament is also essential. In the KKS textbook values are given of the correlations of social skills with selected characteristics of temperament, measured using various tools.

In the case of the temperament questionnaire PTS (questionnaire based on Pawłowska's concept of the features of the nervous system), two out of three of its scales: the strength of the stimulation process and the activity of nervous processes correlate significantly with all scales of the KKS and the total result. The strength of the stimulation process can be regarded as a measure of reactivity in J. Strelau's ${ }^{7}$ regulative theory of temperament (RTT), while activity defines the ability to quickly and adequately respond to changes in the environment.

In light of the above, it can be assumed that high scores on KKS scales mean high enough results in the aforementioned PTS scales (Table no. 4).

In the study presented, the average results for the entire group are within the range of average results. For PTS results, in accordance with the generally accepted criteria, the average result refers to results within the range of 4-7 sten. Therefore, it can be assumed that the average results in the KKS test correspond to the average results in PTS in the scope of scales that correlate with one another.

\footnotetext{
${ }^{7}$ Reactivity is understood as the intensity of responding to stimuli; persons who have low reactivity are characterized by high resistance and endurance, as well as a great demand for stimulation, persons who have high reactivity - vice versa.
} 
Table 4. Correlation of social skills, measured by the KKS questionnaire with temperament characteristics, measured by the PTS questionnaire (significant coefficients at the level of 0.05 have been bolded) (Matczak, 2011, p. 29).

\begin{tabular}{|c|c|c|c|c|}
\hline $\begin{array}{c}\text { KKS } \\
\text { PTS }\end{array}$ & I & ES & A & total result \\
\hline strength of the stimulation process & $\mathbf{0 . 2 4}$ & $\mathbf{0 . 2 5}$ & $\mathbf{0 . 3 1}$ & $\mathbf{0 . 3 3}$ \\
\hline strength of the inhibiting process & 0.14 & 0.06 & 0.17 & 0.15 \\
\hline activity & $\mathbf{0 . 3 8}$ & $\mathbf{0 . 3 7}$ & $\mathbf{0 . 3 1}$ & $\mathbf{0 . 4 5}$ \\
\hline
\end{tabular}

Therefore, it can be assumed that, although we are not dealing here with a high need for stimulation, then these are rather upper registers of average results, which could mean at least a tendency not to avoid stimulation, while sexual activity is a kind of activity that satisfies this need. In addition, it can be assumed that this activity also satisfies a cognitive need.

The thesis above is strengthened by the correlation of KKS with the questionnaire R-I (Matczak 2011, p. 23-29), measuring the demand for cognitive stimulation (scale of activity) and fear of failure (scale of caution). In accordance with the standards for women cited in the KKS textbook (girls of various types of secondary schools), in all KKS scales the results were statistically significant and had positive correlation with the results of the activity scale, and a negative correlation with the results of the scale of caution. At the same time, for the characteristic of caution they were much higher than those for the characteristic of activity.

Noteworthy is also the correlation of the KKS scales with the scales of the questionnaire for testing styles of coping with stress - CISS. The authors of this tool - Norman S. Endler and James D. A. Parker (Polish adaptation: Strelau, Jaworowska, Szczepaniak, Wrześniewski 2003) - declare that they refer to the transactional model of stress in terms of Lazarus. They understand style of coping with stress as typical behaviour for a given individual in a variety of stressful situations.

The scale of the task-oriented style (SSZ) determines the style of coping with stress which relies on undertaking a task. Persons who obtain high scores in this scale tend to make efforts in stressful situations to solve the problem through a cognitive conversion or attempt to change the situation. Emphasis here is placed on the task or planning to solve the problem.

Emotion-oriented style (SSE) concerns a characteristic style for people who in stressful situations tend to focus on themselves, on their own emotional experiences (anger, guilt, tension, etc.). These people also have a tendency for wishful thinking and fantasizing. Such measures aim at reducing emotional tension associated with the stressful situation. Significantly, the results of several studies suggest that focusing on one's own emotions is associated with low levels of social skills (Ibid., p. 50).

The avoidance style (SU) determines the style of coping with stress which is characteristic for people who in stressful situations tend to avoid thinking, agonizing and experiencing this situation. This style can be manifested in committing to substitution activities or searching for social contacts. As the results of studies show, engaging in substitution activities has a negative correlation with general social skills and coping with situations of close interpersonal contact (scale I) (Ibid., p. 51). 
The high correlation coefficient of CISS (SZ) with KKS (SE) and KKS (A) - Table no. 5 - can indicate some similarity of these situations (social skills conditioning the effectiveness of behaviours in situations of social exposure and the effectiveness of behaviours in situations that require assertiveness). Perhaps it should be assumed that these two circumstances converge; in other words, that both variables are characteristic of the same type of environmental interaction (the situation of social exposure is a situation that requires assertiveness. As A. Matczak (2011, p. 5) claims, linking social skills with the ability to realize one's own aims in a way that is socially acceptable (ES scale), makes social exposure "close to the concept of assertiveness, and maybe even identical to it".

Table 5. Correlation of social skills, measured by the KKS questionnaire with personality characteristics, measured by the CISS (secondary school students $n=148 ;$ K81, M67) (significant coefficients at the level of 0.05 have been bolded) (Matczak 2011., p. 30).

\begin{tabular}{|c|c|c|c|c|}
\hline $\begin{array}{c}\text { KKS } \\
\text { CISS }\end{array}$ & I & ES & A & total result \\
\hline Task style & 0.13 & $\mathbf{0 . 3 9}$ & $\mathbf{0 . 3 2}$ & $\mathbf{0 . 3 7}$ \\
\hline Emotion style & 0.08 & -0.16 & $\mathbf{- 0 . 2 5}$ & -0.14 \\
\hline Avoidance style & $\mathbf{0 . 3 4}$ & $\mathbf{0 . 2 0}$ & 0.07 & $\mathbf{0 . 2 3}$ \\
\hline
\end{tabular}

While the high coefficient of correlation of CISS (U) with KKS (I), along with the statistically significant, albeit a fairly low coefficient of correlation with KKS (ES) may mean that in intimate situations (and thus to a large extent situations unstructured by norms, enabling to be based on the algorithms of well-known socialization processes and not requiring their internalization, but only their knowledge), that is, in situations of uncertainty as to the forms of behaviour, these people tend to take on substitute activities.

For the results of the KKS study at the average level it can be assumed (based on the correlations mentioned above) that similar results in the scope of CISS could also probably characterize the persons surveyed. The results at the average level for both features, as in the case of the alliance of KKS/PTS, do not have to mean the existence of clear, polarized configurations, but may indicate certain trends in mutual relations.

This means that with the persons surveyed in intimate situations, we can be dealing with some kind of caution, and perhaps withdrawal, different than in situations of social exposure, which are much more clearly defined in terms of custom standards.

At the same time, however, in the case of correlation of KKS with R-I, these correlations are reversed for KSS and R-I (Caution). In this case, this may yield the general question of tendencies of the surveyed persons to behave cautiously. Perhaps intimate situations are a specific type of situation, which are identified as situations of uncertainty. On the other hand, however, there is no assurance that situations which result in girls undertaking sexual behaviour are identified by them as intimate situations.

In addition, there can also be a clear difference between undertaking sexual behaviour, and undertaking the same behaviours with conceiving a child in mind. In other words, on the basis of the studies conducted, it cannot be determined whether pregnancies and motherhood were the result of a coincidence or if they were intentional. 


\section{CONCLUSIONS AND RECOMMENDATIONS}

The study results presented in this paper demonstrate the high demand of the surveyed population of girls for stimulation, including cognitive stimulation. That is why the Authors of the studies stand by the opinion that underage mothers and pregnant charges residing in correctional institutions should be ensured with such living conditions, and such a socioeducational environment should be created, which shall satisfy their needs and individual requirements through adequate stimulation.

It seems that in achieving a high effectiveness of resocializing actions, the component of co-decision-making may play a significant role, for research has shown that the girls studied possessed an internal locus of control, both in terms of successes and failures - and let us remember that people with internal LOC strongly identify with the effects of their own actions, regardless of whether they have been successful or failed in their outcome.

Therefore, if underage mothers and pregnant charges of correctional institutions are provided with an environment which they themselves shape and form their own activity, it can be expected that they will greatly identify with this created environment, and shall not seek substitute activities.

Due to the fact that part of the analyses conducted, and thus the conclusions of the studies, are based on including intermediate variables to the concluding process (cited correlations of KKS and KBPK with PTS, CISS and IR questionnaires), then on the one hand, it can be assumed that the predictions described are adequate, but on the other hand, it should be remembered that the formulated conclusions are not the result of directly conducted studies, but only an anticipation based on a series of analyzed dependencies. Thereby, also, in accordance with the above suggestions, it is essential to continuously monitor both the functioning of girls in this kind of environment, as well as specify any possible changes obtained as a result of resocialization effects. In other words, it is about the systematic evaluation of the accuracy of derived conclusions and examining the effectiveness of the measures undertaken on their basis.

The result of the study, and especially the strong correlation of avoidance strategies for coping in situations of interpersonal intimacy points to the legitimacy of applying methods of creative resocialization when working with underage mothers and pregnant charges of correctional institutions.

Creative resocialization involves stimulating dormant human potential through the development of cognitive structures (emotions, imagination, thinking, motivation, perception, memory). It is understood as a process of controlled modification (rather than deleting or decompleting) of fixed deviant identities, and is done by providing the individual with new information and shaping skills in the course of methodical development of structural factors of cognitive processes, as a result of which changes occur, and as a consequence, the transition:

1) from physiognomic perception to allocentric perception;

2) from instrumental motivation to self-creative motivation;

3) from negative emotions to positive emotions;

4) from stereotypical thinking to creative thinking;

5) from reproductive imagination to creative imagination;

6) running a smooth recovery information from the archives of long-term memory.

In the process of becoming aware of deepened thinking about one's own characteristics and observing them in the form of externalized self-presentation, the individual locates in himself/herself features and feelings that are identical to the image created by them. This 
leads to refocusing the structure of "I" and incorporating newly learned characteristics in the structure of identity parameters. As a result, through the self-creation and acceptance by the individual of the new, positive status of a person (individual and social) - an ex-deviant identity is formed, which is socially correct (Konopczyński 2006). It should be understood as a functional way of thinking about oneself and one's life priorities in the context of their social acceptance (Giddens 2010). Importantly, the functionality of this type of thinking relies on undertaking new social roles. Educational support of underage mothers and pregnant charges of correctional institutions would, therefore, constitute in stimulating the development of their potentials (talents, interests, personal predispositions) and lead to the social instilment of the obtained developmental effects ${ }^{8}$. Resocialization goals should focus on discovering and modifying diverse cognitive structures, and integrating mental functions, which enable to achieve an adequate level of interpersonal maturity. This would mean taking multifaceted actions oriented at both the girls and their social environment, as well as on the factors and structures that could help or harm them in the process of their resocialization, and in the final stage - redevelopment and social reintegration.

To sum up, the result of the research carried out in conjunction with the dependencies between various indicators defined in the cited works provides a basis for building appropriate educational strategies and may provide a starting point for creating a model of help and support activities. The process of social support of a specific group of minors - mothers and pregnant charges of correctional institutions, should be aimed at strengthening their skills and making systemic changes with regard to creating opportunities of juvenile mothers to function together with their children in correctional institutions or in other, properly adapted institutions. However, this requires carrying out in-depth theoretical analyses and empirical studies aimed at selecting optimum methods and forms of resocialization effects.

Their implementation should, however, be associated with the necessity of monitoring and systematically evaluating the specialist programme of effects, focused primarily on the measurement and evaluation of the effectiveness of the resocialization process and its optimization. Thereby, the Authors of this paper are convinced that the study of underage mothers and pregnant charges of correctional institutions should be longitudinal, and should also provide a control group in the methodology.

It should also be remembered that in accordance with the results of research, focusing solely on one aspect of the proposed solutions, i.e. on creating conditions for joint functioning of mothers with children may not be sufficient, because without additional measures that increase the attractiveness of this environment for girls, it will be an "idle" environment for them in terms of their need for stimulation. In this case, as it has already been mentioned, such a situation may generate trends in the charges to undertake substitute activities, which compensate the lack of stimulation. Importantly, it can be stipulated that the implication of these types of activities will be negligence with regard to caring for the children.

\section{BIOGRAPHY}

BEATA MARIA NOWAK: PhD in humanities in the field of pedagogy. Professor at the Higher School of Social Sciences Pedagogium in Warsaw: member of the Scientific Board, deputy director of the Institute of Social Sciences for scientific research and the head of the Scientific and Research Academy of Pedagogium and postgraduate studies. Member of the Correctional Pedagogy Committee within the Pedagogical Sciences

\footnotetext{
${ }^{8}$ Potential should be understood as an elevated level of the quality of the performance of structural factors and
} mechanisms of creative processes creating new parameters (cf. identity requirement. Konopczyński 2006). 
Committee of the Polish Academy of Sciences. Member of the Scientific Board of the Institute of Interdisciplinary Studies in Brno (Czech Republic). Editor of the yearly publication 'Resocjalizacja Polska Correctional system in Poland.' Expert and team member in Polish and international research and scientific projects.

\section{Selected scientific publications \\ Monographs:}

B. M. Nowak, Rodzina w kryzysie. Studium resocjalizacyjne, PWN, Warszawa 2011 (next ed. 2012).

B. M. Nowak, Internaty i bursy szkolne w funkcji wyrównywania szans edukacyjnych młodzieży, Wyd. WSZiA, Zamość 2006.

\section{Edited works}

B. M. Nowak, J Krawczyk (ed.), Problemy współczesnej pedagogiki szkolnej, Wyd. Pedagogium, Warszawa 2014 (in print)

M. Kolankiewicz, B. M. Nowak (red.), Rodzinne Domy Dziecka - w stronę rozwoju kompetencji, Wyd. Fundacji Orlen, Warszawa 2013;

L. Pytka, B. M. Nowak (ed.), Problemy współczesnej resocjalizacji, Wyd. Pedagogium, Warszawa 2010;

M. Konopczyński, B. M. Nowak (ed.), Resocjalizacja - ciagłość i zmiana, Wyd. Pedagogium, Warszawa 2008.

JACEK KRAWCZYK: MA in psychology from the University of Warsaw, PhD student at Higher School of Social Sciences Pedagogium in Warsaw, (the subject of his $\mathrm{PhD}$ dissertation is: Adaptation strategies of junior high school pupils and teachers. Pedagogical and psychological perspective). His scientific and research interests are related to evolutionary psychology, neuropsychology, psychology of temperament and recently also anthropology and ethnology. Professionally, he has been related for many years with state administration Ministry of Education and National School of Public Administration (KSAP). Faculty member of universities where he teaches psychology, co-editor of the publication: B. M. Nowak, J. Krawczyk (ed.), Problemy współczesnej pedagogiki szkolnej, Wyd. Pedagogium, Warszawa 2014 (in print).

\section{References}

[1] Adler R. B., Rosenfeld L. B., Proctor R. F., Relacje interpersonalne, Wyd. Rebis, Poznań 2006.

[2] Czarnota-Bojarska J., Obserwacyjna samokontrola a funkcjonowanie w grupie, "Psychologia Wychowawcza" 1997, no. 40.

[3] Domachowski W., Kowalik S., Miluska J. (ed.), Z zagadnień psychologii społecznej, PWN, Warsaw 1984.

[4] Giddens A., Nowoczesność i tożsamość, PWN, Warsaw 2010.

[5] Jaworowska A., Matczak A., Test Niedokończonych Zdań Rottera RISB. Textbook, PTP, Warsaw 2003.

[6] Konopczyński M., Metody twórczej resocjalizacji, PWN, Warsaw 2006.

[7] Krasowicz G., Kurzyp-Wojnarowska A., Kwestionariusz do badania poczucia kontrolitextbook, PTP, Wydział Psychologii UW, Laboratorium Technik Diagnostycznych im. Bohdana Zawadzkiego, Warsaw 1990.

[8] Matczak A., Kwestionariusz kompetencji Społecznych. Textbook, PTP, Warsaw 2011.

[9] Matczak A., Kwestionariusz Kompetencji Społecznych. Textbook, PTP, Warsaw 2007.

[10] Matczak A., Temperament a kompetencje społeczne [in:] W. Ciarkowska, A. Matczak (ed.), Różnice indywidualne: wybrane badania inspirowane Regulacyjna Teoria temperamentu Profesora Jana Strelaua, Wyd. UW, Warsaw 2001. 
[11] Nowak B. M., Rodzina w kryzysie. Studium resocjalizacyjne, PWN, Warsaw 2012.

[12] Oppenheimer L., The nature of social action, [in:] B. H. Schneider i in (ed.), Social competence In developmental perspective, p. 41-69, Kluwer Academic Publishers 1989.

[13] Smółka P., Kompetencje społeczne. Metody pomiaru i doskonalenia umiejętności interpersonalnych, Wyd. Wolters Kluwer, Kraków 2008.

[14] Spitzberg B. H., Cupach W. R., Interpersonal Skills, [in:] H. L. Knapp, J. A. Daly, Handbook of Interpersonal Communication, Sage, Thousand Oaks 2002.

[15] Strelau J., Jaworowska A., Szczepaniak P., Wrześniewski K., Kwestionariusz radzenia sobie w sytuacjach stresowych CISS, PTP, Warsaw 2003.

[16] Strelau J., Psychologia różnic indywidualnych, Scholar, Warsaw 2002.

[17] Świątnicki K., Teoria stylów monitorowania się, "Studia Psychologiczne" 1994, XXXI.

[18] http://www.podrugie.pl/wp-content/uploads/2013/11/RAPORT.pdf._Raport z realizacji projektu "Chcę być z Tobą MAMO!" (co-financed by Fundacja im. Stefana Batorego), Sytuacja prawna, społeczna $i$ wychowawcza nieletnich ciężarnych i nieletnich matek przebywajacych w placówkach resocjalizacyjnych, Fundacja po DRUGIE (Sikora A. (development and editing). 